Int. J. Electrochem. Sci., 14 (2019) $8750-8759$

International Journal of

ELECTROCHEMICAL

SCIENCE

$\underline{\text { www.electrochemsci.org }}$

\title{
Enhanced Corrosion Resistance of AZ91D Magnesium Alloy by Electric Field - Assisted Anodizing
}

\author{
Xinjian Song, Yujun Si ${ }^{*}$, Jin Liu, Minjiao Li, Zhongping Xiong \\ College of Chemistry and Environmental Engineering, Sichuan University of Science and Engineering, \\ Zigong, 643000, China \\ *E-mail: syj08448@,163.com
}

doi: $10.20964 / 2019.09 .14$

Received: 22 April 2019 / Accepted: 12 June 2019 / Published: 31 July 2019

\begin{abstract}
An external electric field was imposed on electrolytic cell in anodization of AZ91D magnesium alloy. The anodizing process became more stable with the assistance of the external electric field, and the obtained anodization film was smoother and compact. As a result, the corrosion resistance of the anodization film was enhanced. The external electric field can drive the anions in the electrolyte, especially the citrate ion with more negative charge and larger volume, to migrate to the surface of the AZ91D electrode to form the anodization film. The greatest carbon content could be obtained at an $8 \mathrm{~V}$ of external electric field, which corresponded to the best microstructure and corrosion resistance of the anodization film.
\end{abstract}

Keywords: Magnesium alloy; Anodizing; External electric field; Ionic motion; Corrosion resistance

\section{$\underline{\text { FULL TEXT }}$}

(C) 2019 The Authors. Published by ESG (www.electrochemsci.org). This article is an open access article distributed under the terms and conditions of the Creative Commons Attribution license (http://creativecommons.org/licenses/by/4.0/). 